\title{
Isolated non-autoimmune neutropenia revealing primary hypothyroidism
}

\author{
Bouomrani $\mathrm{S}^{1,2 *}$ and Rgaïeg $\mathrm{N}^{1}$ \\ ${ }^{1}$ Department of Internal medicine, Military Hospital of Gabes, Tunisia \\ ${ }^{2}$ Sfax Faculty of Medicine, University of Sfax, Tunisia
}

\begin{abstract}
Introduction: hematological disorders are among the so-called unusual manifestations of hypothyroidism, and by far dominated by anemia. Leucocytes abnormalities are less common and often of an autoimmune nature. We report an original case of isolated non-autoimmune neutropenia revealing primary severe hypothyroidism.

Case report: A 30-year-old woman was referred by her family doctor for exploration of leucopenia at 3200/ $\mathrm{mm}^{3}$. Control of the blood count confirmed isolated neutropenia at $600 / \mathrm{mm}^{3}$. The other parameters of the total blood count were without abnormalities: hemoglobin at $13 \mathrm{~g} / \mathrm{dl}$, platelets at $162000 / \mathrm{mm}{ }^{3}$, and lymphocytes at $2400 / \mathrm{mm}^{3}$.

Clinical examination, baseline bioassays, abdominal ultrasonography, thoraco-abdominopelvic CT, and myelogram were without abnormalities. Anti-nuclear, antinative DNA, anti-nucleosome, and anti-neutrophil antibodies were negative.

Subsequent investigations concluded to primary hypothyroidism of Hashimoto's thyroiditis: TSH at 182 $\mu \mathrm{U} / \mathrm{ml}, \mathrm{FT} 4<1$ pmol/1, anti-thyroglobulin antibodies at 255 $\mathrm{IU} / \mathrm{ml}$, and anti- thyroperoxidase antibodies at $1000 \mathrm{IU} / \mathrm{ml}$. The patient was treated with thyroxine in progressive doses until normalization of TSH with $175 \mu \mathrm{g} / \mathrm{d}$. The evolution was favorable with neutrophils at $2200 / \mathrm{mm}^{3}$ after one month of treatment.
\end{abstract}

Conclusion: Isolated and non-autoimmune neutropenia indicative of hypothyroidism is exceptional and unusual representing a real diagnostic challenge for clinicians. It is recommended to screen for thyroid dysfunction in front of any leucopenia that does not prove itself.

\section{Introduction}

Hypothyroidism is one of the most common endocrinopathies in the world with an estimated prevalence of $0.3-3.7 \%$ for overt or symptomatic forms [1] and more than $10 \%$ for subclinical or asymptomatic forms [2]. This prevalence can be as high as $20 \%$ in subjects over 60 years of age, especially women [3,4], and it is estimated that $2.5 \%$ of subjects with subclinical form progress to overt hypothyroidism annually [5].

Despite their frequency and ease of diagnosis, these endocrinopathies remain underdiagnosed; in fact, a meta-analysis of studies in nine European countries estimated the prevalence of undiagnosed cases of hypothyroidism (both overt and subclinical) at $5 \%$ of the general population [6]. The large polymorphism of clinical and biological manifestations associated with hypothyroidism explains the under-diagnosis of this disease [7-11].

Hematological disorders are among the so-called unusual manifestations of hypothyroidism [12]. They are therefore very little known and often overlooked by health practitioners [12]. Hematological manifestations of hypothyroidism are by far dominated by anemia $[12,13]$ and pancytopenia $[14,15]$. Leucopenia/neutropenia are much rarer and unusual [16] and are classically autoimmune in nature (autoimmune neutropenia associated with autoimmune thyroiditis) $[17,18]$. We report the original case of isolated and non-autoimmune neutropenia revealing primary severe hypothyroidism.

\section{Case report}

A 30-year-old woman with no significant pathological history was referred by her family doctor for exploration of isolated leucopenia at $3200 / \mathrm{mm}^{3}$, found on a systematic check-up. Control of the blood count confirmed isolated leukopenia of neutropenia-type with neutrophils at $600 / \mathrm{mm}^{3}$. The other parameters of the total blood count were without abnormalities: hemoglobin at $13 \mathrm{~g} / \mathrm{dl}$, platelets at $162000 / \mathrm{mm}^{3}$, and lymphocytes at $2400 / \mathrm{mm}^{3}$.

The clinical examination was without particularities. Baseline bioassays were within normal limits: erythrocyte sedimentation rate, C-reactive protein, serum calcium, inonogram, lactic-dehydrogenases, alkaline phosphatase, serum protein electrophoresis, blood glucose, transaminases, muscle enzymes, lipid parameters, and creatinine. Anti-nuclear, anti-native DNA, anti-nucleosome, and anti-neutrophil antibodies were negative.

Abdominal ultrasonography and thoracoabdominopelvic CT were without abnormalities. The myelogram with marrow karyotype

*Correspondence to: Bouomrani S, Department of Internal medicine, Military Hospital of Gabes, Gabes, Tunisia, Tel: +00216 98977555; E-mail: salembouomrani@yahoo.fr

Key words: neutropenia, hypothyroidism, leucopenia, cytopenia, hashimoto thyroiditis, hematological disorders

Received: May 15, 2019; Accepted: May 24, 2019; Published: May 27, 2019 
was also without abnormalities. Subsequent investigations concluded to primary hypothyroidism of Hashimoto's thyroiditis: Thyroid Stimulating Hormone (TSH) at $182 \mu \mathrm{U} / \mathrm{ml}$, free tetraiodothyronine (FT4) $<1 \mathrm{pmol} / \mathrm{l}$, anti-thyroglobulin antibodies at $255 \mathrm{IU} / \mathrm{ml}$, and antithyroperoxidase antibodies strongly positive at $1000 \mathrm{IU} / \mathrm{ml}$.

The final diagnosis was that of a severe subclinical hypothyroidism of Hashimoto's thyroiditis, revealed by isolated non-autoimmune neutropenia. The patient was treated with thyroxine in progressive doses until normalization of TSH with $175 \mu \mathrm{g} / \mathrm{d}$. The evolution was favorable with progressive normalization of the leucocyte count. Neutrophils were at $2200 / \mathrm{mm}^{3}$ after one month of treatment.

\section{Discussion}

Hematological manifestations during hypothyroidism are dominated by anemia $[12,13]$ with a wide variety of anemic disorders (normocytic, microcytic, and macrocytic) [13], and sometimes even severe pancytopenia $[14,15]$. More rarely are platelet function abnormalities, and coagulation factor alterations [19]. Leucocytes abnormalities are much rarer and unusual during hypothyroidism [16] but can sometimes be severe with even cases of agranulocytosis [20].

The exact frequency of leuco-neutropenia during hypothyroidism is not well known due to lack of studies. In an Algerian study presented at the 34th Congress of the French Society of Endocrinology in 2017, Haddam AEM et al reported a frequency of $6 \%$ of leucopenia in their series of 150 untreated hypothyroid patients [21]. The following year, and at the 35th congress of the same society, the Tunisian team of Guizani $\mathrm{N}$ et al reported a frequency of $4 \%$ of leucopenia in their series of 67 hypothyroid patients [22]. This frequency seems to be very underestimated since in the Kyritsi EM et al study of 218 patients investigated for neutropenia, 95 had a thyroid disorder (43.6\%) and half had hypothyroidism [18]. This same study showed that the prevalence of hypothyroidism in neutropenic patients is statistically higher than that in the general population: $23.4 \%$ Vs $10.7-13.4 \%$ [18].

Neutropenia associated with hypothyroidism can be exceptionally isolated as in our case, but most often associated with other hematological disorders (anemia, macrocytosis, lymphopenia, and thrombocytopenia) $[16,23,24]$. It is classically mild to moderate but can exceptionally be severe [20].

The exact physiopathological mechanism of this neutropenia is not well understood. It may be a direct repercussion of thyroid hormone deficiency on the various stages of hematopoiesis [25], in particular granulopoiesis [18], or an autoimmune mechanism (autoimmune neutropenia with positive anti-neutrophil antibodies) during hypothyroidism of autoimmune thyroiditis $[17,18]$.

These hematological disorders may be the dominant signs of the clinical picture of this endocrinopathy or, exceptionally, the only signs revealing or inaugurating the disease $[12,24]$. Hematological disorders, including leucopenia/neutropenia, typically respond favorably to hormone replacement therapy for hypothyroidism [12]. Failure to correct these hematological abnormalities with hormone replacement therapy should be suggestive of underlying hematologic malignancies (acute myeloid leukemia or myelodysplastic syndrome) [23].

\section{Conclusion}

Isolated leucopenia/neutropenia indicative of hypothyroidism is very rare and unusual representing a real diagnostic challenge for clinicians. Non-autoimmune forms related to a direct effect of thyroid hormone deficiency are exceptional and respond favorably to treatment with thyroxine. Their knowledge by all health practitioners is necessary to avoid diagnostic delays and costly and often unnecessary investigations. Thus, hypothyroidism should be considered in the differential diagnosis of neutropenia and it is recommended to screen for thyroid dysfunction in front of any leukopenia that does not prove itself.

\section{Conflict of interest}

\section{None}

\section{References}

1. Chaker L, Bianco AC, Jonklaas J, Peeters RP (2017) Hypothyroidism. Lancet 390: 1550-1562. [Crossref]

2. Udovcic M, Pena RH, Patham B, Tabatabai L, Kansara A (2017) Hypothyroidism and the Heart. Methodist Debakey Cardiovasc J 13: 55-59. [Crossref]

3. Baumgartner C, Blum MR, Rodondi N (2014) Subclinical hypothyroidism: summary of evidence in 2014. Swiss Med Wkly 144: w14058. [Crossref]

4. Decandia F (2018) Risk factors for cardiovascular disease in subclinical hypothyroidism Ir J Med Sci 187: 39-43. [Crossref]

5. Redford C, Vaidya B (2017) Subclinical hypothyroidism: Should we treat? Post Reprod Health 23: 55-62. [Crossref]

6. Garmendia Madariaga A, Santos Palacios S, Guillén-Grima F, Galofré JC (2014) The incidence and prevalence of thyroid dysfunction in Europe: a meta-analysis. $J$ Clin Endocrinol Metab 99: 923-931. [Crossref]

7. Bouomrani S, Lassoued N, Ben Hamad M, Regaïeg N, Belgacem N, et al. (2018) Recurrent Intestinal Obstruction Revealing Hypothyroidism. Arch Gastroen Hepat 1: $22-25$.

8. Bouomrani S, Regaieg N, Belgacem N, Ben Hamed M, Lassoued N, et al. (2018) Myositis-Like Syndrome Revealing Hypothyroidism. Arch Diab Endo Sys 1: 1-3.

9. Salem Bouomrani, Regaïeg N, Ben Hamad M, Lassoued N, Belgacem N, et al. (2018) An Unexpected Etiology of Rhizomelic Pseudo-Polyarthritis (Polymyalgia Rheumatica) in the Elderly. Arch Orthop Rheuma 1: 12-16.

10. Bouomrani S, Guermazi M, Yahyaoui S, Trabelsi S, Ghanmi L (2019) Depression of the elderly revealing a primary hypothyroidism. Adv Gen Pract Med 2: 1-4.

11. Bouomrani S, Guermazi M, Yahyaoui S, Nouma H (2018) Acute Hepatitis-Like Syndrome Revealing Hashimoto Thyroiditis. Sci J Gastroenterol \& Hepatol 1:1-3.

12. Klein I, Levey GS (1984) Unusual manifestations of hypothyroidism. Arch Intern Med 144: 123-128. [Crossref]

13. Erdogan M, Kösenli A, Ganidagli S, Kulaksizoglu M (2012) Characteristics of anemia in subclinical and overt hypothyroid patients. Endocr J 59: 213-220. [Crossref]

14. Tsoukas MA (2014) Pancytopenia in severe hypothyroidism. Am J Med 127: e11-12. [Crossref]

15. McMahon B, Kamath S (2016) Pancytopenia in a Patient with Hypothyroidism. JAMA 315: 1648-1649. [Crossref]

16. Sugiura Y, Itoh K, Hakumei O, Asai T, Fujioka S, et al. (1982) A case of pure red cell aplasia associated with thymoma, granulocytopenia, hypogammaglobulinemia, and hypothyroidism. Rinsho Ketsueki 23: 700-777. [Crossref]

17. Lynfield YL, Green K, Gopal R (1983) Bullous pemphigoid and multiple autoimmune diseases. Alopecia universalis, bullous pemphigoid, hypothyroidism, rheumatoid arthritis, and neutropenia in one patient. J Am Acad Dermatol 9: 257-261. [Crossref]

18. Kyritsi EM, Yiakoumis X, Pangalis GA, Pontikoglou C, Pyrovolaki K, et al. (2015) High Frequency of Thyroid Disorders in Patients Presenting with Neutropenia to an Outpatient Hematology Clinic STROBE-Compliant Article. Medicine (Baltimore) 94: e886. [Crossref]

19. Klein M, Barbé F, Kaminsky P, Duc M (1993) [Disorders of hemostasis in dysthyroidism]. Pathol Biol (Paris) 41: 268-275. [Crossref]

20. Pillay K (1998) Congenital hypothyroidism and immunodeficiency: evidence for an endocrine-immune interaction. J Pediatr Endocrinol Metab 11: 757-761. [Crossref]

21. Haddam AEM, Meskine D (2017) Les anomalies hématologiques dans l'hypothyroïdie Annales d'Endocrinologie 78: 349. 
22. Guizani N, Mzabi A, Sboui G, Mkaouar F, Rezgui A, et al. (2018) Les anomalies hématologiques de l'hypothyroïdie. Annales d'Endocrinologie 79: 366-367.

23. Boonen AL, Lefèbvre C, Lambert M, Ferrant A, Michaux JL, et al. (1992) Hypothyroidism associated with myeloid neoplasia. About 2 cases. Acta Clin Belg 47: 397-400.
24. Rubio Barbón S, Fernández Ordóñez JA, Velasco Alvarez A, Aguirre Losada A, Alvarez Carreño F, et al. (1990) Myopathy and bicytopenia as the first manifestation of primary autoimmune hypothyroidism, apropos a case. An Med Interna 7: 438-439. [Crossref]

25. Dorgalaleh A, Mahmoodi M, Varmaghani B, Kiani Node F, Saeeidi Kia O3, et al (2013) Effect of thyroid dysfunctions on blood cell count and red blood cell indice. Iran J Ped Hematol Oncol 3: 73-77. [Crossref]

Copyright: $@ 2019$ Bouomrani S. This is an open-access article distributed under the terms of the Creative Commons Attribution License, which permits unrestricted use, distribution, and reproduction in any medium, provided the original author and source are credited. 